\title{
Evaluation of Fatty and Amino Acids Profile, Sensory and Microbial Loud of Chicken Luncheon Prepared with Lentil Powder, Turnip Plant and Cauliflower \\ Aly, A. A. and H. A. Morsy \\ Home Economics Department, Faculty of Specific Education, Benha University, Egypt
}

\section{ABSTRACT}

The aim of this study was to use some plants such as lentils (Lens culinaris), turnip plant (Brassica rapa) and cauliflower (Brassica oleracea) in processing of chicken luncheon to low cost of production and promote nutritional value. Treatments of chicken luncheon samples included: a) control luncheon (CL) Basal formula without any additional ingredients, b) Basal formula + lentils powder (T1), c) Basal formula + fresh turnip plant roots (T2), d) Basal formula + fresh cauliflower (T3) and f) (T4) Basal formula + lentils powder + fresh turnip plant roots + fresh cauliflower. Some parameter of chicken luncheon produced from different treatments included saturated and unsaturated fatty acids, amino acids, sensory attributes and microbial loud were evaluated. The total saturated fatty acids for oils extracted from CL, T1 and T2 treatments were 41.15, 40.15 and $40.18 \%$, while the total unsaturated fatty acids amounted to $58.75,59.83$ and $59.80 \%$, respectively and the palmitic acid presented the predominant saturated fatty acids, while oleic acid was the highest unsaturated fatty acids. Leucine is the major essential amino acid in chicken luncheon treatments. It was $4.41 \%$ for T2 sample and $4.49 \%$ for T1 sample. Glutamic acid showed higher ratio of non-essential amino acid ranged between $8.97 \%$ (T2) and 9.75\% (control sample). The results showed that additive lentils, turnip plant and cauliflower to chicken luncheon samples during its preparation decreased and retarded the growth of total molds \& yeasts, total bacterial, psychrophilic bacteria and spore-forming bacteria of chicken luncheon samples during cold storage at $4 \pm 1{ }^{\circ} \mathrm{C}$, hence $\mathrm{T} 1$ and $\mathrm{T} 2$ increase the shelf life of chicken luncheon samples to four months compared other samples (Three months).The applied additive from lentils and turnip plant also improved the appearance, color, texture, taste and odor of the chicken luncheon samples. It was concluded that the activity of lentils and turnip plant as natural antimicrobial assay to control microbial load of chicken luncheon samples, should be used as a food additive to improve the safety of chicken products.

Keywords: Chicken luncheon, Chemical composition, Fatty acids, amino acids, microbial loud; Lentils, Turnip plant Cauliflower.

\section{INTRODUCTION}

Poultry meat has organoleptic, desirable nutritive properties, it is economic, quick, easy to prepare and low in fat compared to other meats, chicken have a significant decrease in total cholesterol (Gross et al., 2002 and Mohamed, 2014). The main ingredients of luncheon formula including beef from flank and topside, starch or soya protein flour, salt, ice water, ascorbat and chicken, final product of luncheon characteristics are affected by raw materials formulation. The chemical composition of luncheon ranged from $61.0 \%$ to $63.5 \%$ for moisture, $13.8 \%$ to $19.5 \%$ for protein, $19.6 \%$ to $15.8 \%$ for fat and $3.7 \%$ to $4.0 \%$ for ash (Abdullah, 2007and Mohammed, 2013). Luncheon meat is a popular food item in many countries and used as fast food (Al-Bachir and Mehio, 2001).Quality of luncheon products influenced by the fat content of meat, temperature, and time of processing. Weatherill, (2009) reported that Listeria monocytogenes contaminated luncheon meat from a biofilm found during a slicer. So, sodium diacetate and sodium acetate used as antimicrobials for processed meat to microbial control on surfaces. Plant activities influence on their contamination (Lundén, et al., 2003). Listeria monocytogenes responsible for $83 \%$ of foodborne illness in ready-to-eat foods involved luncheon (Islam et al., 2002 and Crandall et al., 2015). Luncheon meat has demonstrated that luncheon meats sliced subjected to a significantly higher $L$. monocytogenes contamination (Gombas, et al., 2003 and USDA, 2009). Many fruits and plants contain various amounts of phenolic compounds, including gallic and ellagic acids, which are represent antiviral activity and antimicrobial in vivo as well as in vitro (Leusink et al., 2010; Rozoy, et al., 2013 and Saucier, 2016). The major amino acids of lentil were glutamic acid followed by aspartic acid, leucine acid, arginine acid and lysine acid (Bamdad, et al., 2006; Hefnawy, 2011; Jarpa-Parra et al., 2014 and Sun, et al., 2018), reported that interact of functional side chain groups with some starch hydroxyl groups, hence can utilize as a crosslinking agent. Amino acids of lentil can interact with carbonyl group of $\mathrm{N}$-substituted glycosylamine and starch glucoses producing water (Su, et al., 2012). Starch materials of lentil proteins used as antimicrobials and antioxidants to prolong the shelf life of some foods (López de Lacey, et al., 2014; Medina-Jaramillo, et al., 2017 and Ochoa-Yepes, 2019). The unsaturated essential fatty acids of lentils ranged from $77.5 \%$ to $81.7 \%$, total tocopherols was $37-641 \mathrm{~g} / \mathrm{g}$ on DW and carotenoid ranged from $64 \%$ to $78 \%$ and the2,2diphenyl-1- picrylhydrazyl (DPPH) activity of carotenoids and tocopherols were 0.4893 and $0.3259 \mathrm{~g} / \mathrm{g}$, respectively which contributed as a strong antioxidant activity Zhang, et al., (2014). Peptides of lentils seeds have antimicrobial potential agenist Lens culinaris and antifungal activity against Botrytis cinerea and Neurospora crassa (Shenkarev et al., 2014 ; Pina-Pérez and Ferrús Pérez, 2018). Turnip contain a high amount of glucosinolates especially gluconasturtiin which cause protection against pathogens, antimicrobial and anticancer activities in humans (Fahey et al., 2001; Zhang et al., 2008; Aires et al., 2009 and Thiruvengadam et al., 2016). Phenolics, flavonoids and carotenoids compounds represented as antioxidant, antimicrobial compounds and anticancer activity (Sams et al., 2011). Cauliflower assessed antimicrobial potential against Listeria monocytogenes. It has as sources of antioxidant and fibers. These bioactive properties is an important for the nutritious quality, healthy, so extensively reported currently (Stojceska, et al., 2008; Volden, et al., 2009 and Sanz-Puig et al., 2015). The aims of this study use some plants (lentils, turnip plant and cauliflower) with their bioactive compounds to improve chicken luncheon quality and shelf life. This study aims to assess the quality of chicken luncheon which prepared with lentils, turnip plant and cauliflower additives by parameters used in quality control included chemical composition, fatty acids and amino acids profiles sensory and microbiological evaluation during cold storage at $\left(4 \pm 1^{\circ} \mathrm{C}\right)$. 


\section{MATERIALS AND METHODS}

Materials

1. Chemicals : were purchased from Sigma-Aldrich Company. All ingredients of chicken luncheon were obtained from local markets in Cairo, Egypt.

\section{Preparation of chicken luncheon}

Fresh chicken luncheon was prepared according to formula described by Al-Bachir and Mehio (2001) prepared as follows ingredients in Table (1) with adding lentils (Seed powder), fresh turnip plant (roots) and fresh cauliflower $(\mathrm{w} / \mathrm{w})$ then chicken luncheon samples were packaged stored in cold refrigerator at $4 \pm 1^{\circ} \mathrm{C}$. Sensory, chemical and microbial evaluations of chicken luncheon samples under investigation were determined every one month during storage (Four months) at refrigerator temperature $\left(4 \pm 1^{\circ} \mathrm{C}\right)$. The treatments of chicken luncheon and their abbreviations showed in Table (2).

Table 1. Basal ingredients of chicken luncheon formula

\begin{tabular}{lc}
\hline Ingredients & Gram \\
\hline Chicken meat & 780 \\
Eggs & 70 \\
Flour & 40 \\
Salt & 20 \\
Dried milk & 30 \\
Spices & 10 \\
Soybean powder & 40 \\
Ground garlic & 10 \\
\hline Total & 1000 \\
\hline
\end{tabular}

Table 2. Ingredients and abbreviations of chicken luncheon treatments

\begin{tabular}{lcc}
\hline Treatment & Ingredients & Abbreviation \\
\hline 1 & $\begin{array}{c}\text { Basal formula (1000 gm) } \\
\text { Table(1) }\end{array}$ & $\begin{array}{c}\text { Control luncheon } \\
\text { ( CL) }\end{array}$ \\
\hline 2 & $\begin{array}{c}\text { Basal formula(1000 gm) }+ \\
\text { 200gm of lentils seeds } \\
\text { powder }\end{array}$ & $\begin{array}{c}\text { Lentils luncheon } \\
\text { (T1) }\end{array}$ \\
\hline 3 & $\begin{array}{c}\text { Basal formula(1000 gm) + } \\
\text { 200 gm of fresh turnip plant } \\
\text { roots }\end{array}$ & $\begin{array}{c}\text { Turnip plant luncheon } \\
\text { (T2) }\end{array}$ \\
\hline 4 & $\begin{array}{c}\text { Basal formula(1000 gm) + } \\
\text { 200gm of fresh cauliflower }\end{array}$ & $\begin{array}{c}\text { Cauliflower luncheon } \\
\text { (T3) }\end{array}$ \\
\hline \multirow{4}{*}{$\begin{array}{c}\text { Basal formula(1000 gm) } \\
+66.5 \text { gm of lentils seeds }\end{array}$} & $\begin{array}{c}\text { Collected luncheon } \\
\text { (T4) }\end{array}$ \\
& powder +66.5 gm fresh turnip \\
plant roots +66.5 gm of fresh & cauliflower & \\
\hline
\end{tabular}

\section{Methods}

\section{Gross Chemical composition}

Chemical composition of chicken luncheon and all treatments (Moisture, lipids, protein, crude fibers and ash) examined according to AOAC, (2016), and total carbohydrates were calculated according to the method published by Egan et al., (1981) as the following:

Percent of total carbohydrates $=\mathbf{1 0 0}-($ percent of $($ moisture + crude protein + total lipids + ash + crude fibers).

2 Fatty acids profile

Fatty acids profile was determined using gas chromatography technique (GC) according to the methods described by AOAC, (2016).

\section{Amino acids profile}

Amino acid profile was determined using amino acid Analyzer technique as reported by AOAC (2016).

\section{Sensory evaluation}

Sensory evaluation (appearance, color, texture, taste and odor,) of chicken luncheon samples were examined every one month during storage at $4 \pm 1{ }^{\circ} \mathrm{C}$ for five months according to Mohamed et al., (2014).

\section{Microbial determination}

Total bacterial count was counted according to methods described by APHA, (1992). Psychrophilic and spore-forming bacteria counts determined according to FDA, (2002). Total molds and yeasts were counted according to Oxoid (1998).

\section{Statistical analysis}

Data were subjected to statistical analysis using the general linear models procedure of the statistical Analysis System (SAS, 1998)

\section{RESULTS AND DISCUSSION}

\section{Gross chemical composition of different chicken luncheon samples}

Table 3 shows gross chemical composition of different chicken luncheon treatments on dry weight basis. The highest content of moisture content found in (T2) treatment $(66.5 \%)$, while the lowest one was in control sample $(63.5 \%)$. The moisture content of other treatments ranged between $65.1 \%(\mathrm{~T} 1)$ and $65.6 \%$ (T4) and $66.1 \%$ (T3). Total lipids of the T2 treatment was the lowest (2.8\%), while CL treatment had the highest $(4.4 \%)$. Ash content ranged between $8.2 \%$ and $9.3 \%$, this is due to ingredients of chicken luncheon. Protein content of T2 treatment was higher $(51.9 \%)$ while T4 treatment was the lowest ratio of protein $(43.01 \%)$. Fiber content of T1 treatment was the first $1.74 \%$ than the other treatments which ranged between 0.95 $\%$ and $1.38 \%$. Total carbohydrates of T4 treatment were the highest (43.01\%). Meanwhile, the lowest observed in control sample (33.6) and T2, T3 and T1 treatments showed moderate content of carbohydrates $35.42 \%, 34.25 \%$, and $38.56 \%$, respectively). These results are in consistent with the published data reported by Jelen et al., (1982), Mohammed, (2013) and Hayes et al., (2013) they reported that the chemical composition of luncheon ranged from $61.0 \%$ to $63.5 \%$ for moisture, $13.8 \%$ to $19.5 \%$ for protein, $19.6 \%$ to $15.8 \%$ for fat and $3.7 \%$ to $4.0 \%$ for ash.

Table 3. Chemical constituent of different chicken luncheon samples

\begin{tabular}{|c|c|c|c|c|c|}
\hline \multirow{2}{*}{$\begin{array}{l}\text { Chemical } \\
\text { composition }(\%)\end{array}$} & \multicolumn{5}{|c|}{ Treatments } \\
\hline & $\mathbf{C L}^{\mathbf{a}}$ & $\mathbf{T} 1^{b}$ & $\mathbf{T} 2^{\mathbf{c}}$ & $\mathrm{T3}^{\mathrm{d}}$ & $\mathbf{T} 4^{\mathrm{f}}$ \\
\hline Moisture & 63.5 & 65.1 & 66.5 & 66.1 & 65.6 \\
\hline Total lipids* & 4.4 & 3.4 & 2.8 & 4.3 & 4.1 \\
\hline Ash* & 9.3 & 8.2 & 8.5 & 8.9 & 8.6 \\
\hline Crud protein* & 51.46 & 48.1 & 51.9 & 51.6 & 43.01 \\
\hline Fiber* & 1.24 & 1.74 & 1.38 & 0.95 & 1.28 \\
\hline Total carbohydrates* & 33.6 & 38.56 & 35.42 & 34.25 & 43.01 \\
\hline \multicolumn{6}{|c|}{$\begin{array}{l}\text { *\% on dry weight basis } \\
\text { CL }^{\mathrm{a}} \text { : Basal formula without any additional ingredients (Control } \\
\text { luncheon) }\end{array}$} \\
\hline \multicolumn{6}{|c|}{$\begin{array}{l}\text { T1 } \\
\text { T2: Basal formula + lentils seeds powder } \\
2^{\mathrm{c}} \text { : Basal formula + fresh turnip plant roots } \\
\mathrm{T3}^{\mathrm{d}} \text { : Basal formula + fresh cauliflower } \\
\mathrm{T}^{\mathrm{f}} \text { : Basal formula + (Lentils seeds powder + fresh turnip plant roots } \\
\quad+\text { fresh cauliflower) }\end{array}$} \\
\hline
\end{tabular}


Sensory evaluation of different chicken luncheon samples

Evaluation of appearance, color, texture, taste and odor resulted in T2 treatment scoring highly, followed by T1 treatment during period's storage $\left(4 \pm 1^{\circ} \mathrm{C}\right)$ which rejected after four months, while control sample, $\mathrm{T} 3$ and $\mathrm{T} 4$ treatments received significantly $(\mathrm{P}>0.05)$ lower score for evaluated parameters and rejected after three months. Hence, chicken luncheon samples prepared with turnip plant and lentils were scored the best treatment, compared to the other samples (Table 4). This may be due to the effects of flavonoids and phenolic compounds as natural antioxidants. Moreover starch materials of lentil proteins used as antimicrobials and antioxidants to prolong the shelf life of same food (López de Lacey, et al., 2014; MedinaJaramillo, et al., 2017 and Ochoa-Yepes, 2019) Also, turnip contain a high amount of glucosinolates especially gluconasturtiin which cause protection against pathogens, antimicrobial, anticancer activities in humans and improve meat quality and shelf life (Fahey et al., 2001; Zhang et al., 2008; Aires et al., 2009 and Thiruvengadam et al., 2016), Hence improve the sensory attributes via inactivation microbial load and discoloration of surface (Sams et al., 2011; Su et al., 2012 and Sanz-Puig et al., 2015).

Table 4. Changes in the sensory evaluation of different chicken luncheon samples during cold storage $\left(4 \pm 1^{\circ} \mathrm{C}\right)$

\begin{tabular}{|c|c|c|c|c|c|c|}
\hline \multirow{2}{*}{$\begin{array}{l}\text { Sensory } \\
\text { attributes }\end{array}$} & \multirow{2}{*}{$\begin{array}{l}\text { Storage } \\
\text { (months) }\end{array}$} & \multicolumn{5}{|c|}{ Treatments } \\
\hline & & $\mathbf{C L}^{\mathrm{a}}$ & $\mathbf{T 1}^{\mathrm{b}}$ & $\mathbf{T 2}^{\mathrm{c}}$ & T3 $^{\mathrm{d}}$ & $T 4^{f}$ \\
\hline \multirow{5}{*}{ Appearance } & 1 & $8.5 \pm 2.2$ & $8.9 \pm 2.1$ & $9 \pm 1.8$ & $7.3 \pm 1.2$ & $7.1 \pm 0.90$ \\
\hline & 2 & $8.3 \pm 2.1$ & $8.4 \pm 0.50$ & $8.4 \pm 1.6$ & $6.9 \pm 1.2$ & $6.8 \pm 0.98$ \\
\hline & 3 & $7.1 \pm 1.9$ & $7.2 \pm 1.7$ & $7.3 \pm 1.4$ & $5.8 \pm 0.88$ & $5.7 \pm 1.2$ \\
\hline & 4 & (®) & $5.5 \pm 1.1$ & $5.3 \pm 0.9$ & (B) & (B) \\
\hline & 5 & & ® & ® & & \\
\hline \multirow{5}{*}{ Color } & 1 & $8.4 \pm 2.2$ & $8.2 \pm 1.9$ & $8.7 \pm 1.8$ & $7.6 \pm 1.4$ & $7 \pm 0.93$ \\
\hline & 2 & $7.3 \pm 2.1$ & $7.4 \pm 1.7$ & $8.1 \pm 1.5$ & $7.1 \pm 1.03$ & $6.4 \pm 0.61$ \\
\hline & 3 & $7.1 \pm 1.9$ & $6.5 \pm 1.6$ & $7.1 \pm 1.5$ & $6.1 \pm 0.99$ & $5.5 \pm 0.78$ \\
\hline & 4 & (B) & $5.6 \pm 0.98$ & $5.3 \pm 1.2$ & (R) & (B) \\
\hline & 5 & & ( & (B) & & \\
\hline \multirow{5}{*}{ Texture } & 1 & $8.2 \pm 2.3$ & $8.4 \pm 1.9$ & $8.5 \pm 1.7$ & $7.3 \pm 1.1$ & $7.1 \pm 0.90$ \\
\hline & 2 & $7.5 \pm 1.9$ & $7 \pm 1.7$ & $7.7 \pm 1.4$ & $6.4 \pm 0.83$ & $6.4 \pm 0.86$ \\
\hline & 3 & $6.4 \pm 1.6$ & $6.1 \pm 1.3$ & $6.4 \pm 1.2$ & $5.6 \pm 0.78$ & $5.3 \pm 0.86$ \\
\hline & 4 & ( & $5.1 \pm 1.2$ & $5.8 \pm 0.98$ & ® & ® \\
\hline & 5 & & ( & ® & & \\
\hline \multirow{5}{*}{ Taste } & 1 & $8.1 \pm 2.3$ & $8.3 \pm 1.8$ & $8.5 \pm 1.7$ & $7.7 \pm 1.2$ & $7.1 \pm 0.90$ \\
\hline & 2 & $7.5 \pm 1.9$ & $7.5 \pm 1.7$ & $7.9 \pm 1.4$ & $6.7 \pm 1.3$ & $6.5 \pm 0.88$ \\
\hline & 3 & $6.5 \pm 1.7$ & $6.6 \pm 1.4$ & $6.8 \pm 1.3$ & $6.1 \pm 1.1$ & $5.4 \pm 0.88$ \\
\hline & 4 & ® & $5.00 \pm 1.1$ & $5.8 \pm 1.2$ & ( & ( \\
\hline & 5 & & ( & ( & & \\
\hline \multirow{5}{*}{ Oder } & 1 & $8.1 \pm 2.3$ & $8.1 \pm 1.9$ & $8.2 \pm 3.1$ & $7.3 \pm 1.1$ & $7.1 \pm 1.2$ \\
\hline & 2 & $7.3 \pm 1.9$ & $7.4 \pm 1.6$ & $7.5 \pm 1.4$ & $6.7 \pm 0.89$ & $6.5 \pm 0.88$ \\
\hline & 3 & $6.3 \pm 1.8$ & $6.4 \pm 1.4$ & $6.7 \pm 1.4$ & $5.6 \pm 0.89$ & $5 \pm 0.85$ \\
\hline & 4 & (B) & $5.9 \pm 1.1$ & $5.3 \pm 1.5$ & (R) & (B) \\
\hline & 5 & & (B) & (B) & & \\
\hline
\end{tabular}

Fatty acids composition of different chicken luncheon samples

From data presented in Table (5) it can be noticeable that gas chromatographic analysis for oils extracted from different chicken luncheon samples. The total saturated fatty acids for oils extracted from different chicken luncheon samples recorded 41.15, 40.15 and $40.18 \%$, while the total unsaturated fatty acids amounted to $58.75,59.83$ and $59.80 \%$ for oils extracted from CL, T1 and T2 treatments, respectively. The palmitic and stearic acids were predominant saturated fatty acids, while oleic acid came the first unsaturated fatty acids. These results confirmed by Romans et al. (1994) and Mohamed et al., (2014) reported that meat lipids contain less than 50 saturated fatty acids and up to 70 chicken unsaturated fatty acids. Chicken luncheon treatments (T1 and T2) contained higher level of unsaturated fatty acids. This is due to the addition of lentils and turnip plant that contains higher level of unsaturated fatty acids. These results are agreement with those mentioned by Ansorena and Astiasarán (2013) who reported vegetable oils rich in linoleic acid.

Amino acids composition of different chicken luncheon samples

From data presented in Table (6), it can be seen that the essential and non-essential amino acids of chicken luncheon treatments. Leucine is the major essential amino acid and it ranged between $4.41 \%$ (T2 sample) and $4.49 \%$ (T1 treatment), followed by lysine which ranged between $3.70 \%$ (control sample) and 3.84 $\%$ (T1 treatment).

Valine came in the third order with value ranged between $2.89 \%$ (T2) and $3.17 \%$ (control sample). Glutamic acid was the highest it recorded $8.97 \%$ for T2 treatment and $9.75 \%$ for control sample. Aspartic acid was the second order of non-essential amino acids with the percentage ranged between $4.65 \%$ for $\mathrm{T} 2$ treatment and $5.05 \%$ for control sample followed by arginine and alanine. 
Table 5. Fatty acids composition of different chicken luncheon samples

\begin{tabular}{|c|c|c|c|c|}
\hline \multirow{2}{*}{$\begin{array}{l}\text { Fatty acid } \\
(\%)\end{array}$} & & \multicolumn{3}{|c|}{ Treatments } \\
\hline & & $\mathbf{C} \mathbf{L}^{\mathrm{a}}$ & $\mathbf{T 1}^{\mathbf{b}}$ & $\mathbf{T 2}^{\mathrm{c}}$ \\
\hline Capric acid & (C10:0) & 0.52 & 0.59 & 0.61 \\
\hline Lauric acid & $(\mathrm{C} 12: 0)$ & 1.06 & 1.19 & 1.26 \\
\hline Myristic acid & $(\mathrm{C} 14: 0)$ & 3.15 & 3.35 & 3.31 \\
\hline Tetradecenoic acid & $(\mathrm{C} 14: 0 \omega 5)$ & 0.38 & 0.41 & 0.45 \\
\hline Pentadecanoic acid & $(\mathrm{C} 15: 0)$ & 0.54 & 0.53 & 0.54 \\
\hline Palmitic acid & $(\mathrm{C} 16: 0)$ & 24.88 & 25.07 & 25.08 \\
\hline Palmitioleic acid & $(\mathrm{C} 16: 1 \omega 7)$ & 2.93 & 3.02 & 3.00 \\
\hline Heptadecanoic acid & $(\mathrm{C} 17: 0)$ & 0.94 & 0.83 & 0.82 \\
\hline Decatrienoic acid & $(\mathrm{C} 16: 0 \omega 4)$ & 0.18 & 0.17 & 0.18 \\
\hline Stearic acid & $(\mathrm{C} 18: 0)$ & 9.39 & 7.90 & 7.82 \\
\hline Oleic acid & $(\mathrm{C} 18: 1 \omega 9)$ & 35.99 & 36.53 & 36.39 \\
\hline Linoleic acid & $(\mathrm{C} 18: 2 \omega 6)$ & 17.65 & 18.04 & 18.01 \\
\hline Decadienoic acid & $(\mathrm{C} 18: 2 \omega 4)$ & 0.13 & 0.24 & 0.20 \\
\hline Gamma linolenic acid & $(\mathrm{C} 18: 3 \omega 6)$ & 0.19 & 0.20 & 0.17 \\
\hline Linolenic acid & $(\mathrm{C} 18: 3 \omega 3)$ & 0.76 & 0.85 & 0.79 \\
\hline Octadecatetraenoic acid & $(\mathrm{C} 18: 4 \omega 3)$ & 0.27 & 0.27 & 0.26 \\
\hline Arachidic acid & $(\mathrm{C} 20: 0)$ & 0.11 & 0.11 & 0.11 \\
\hline Eicosaenoic acid & $(\mathrm{C} 20: 1 \omega 11)$ & 0.11 & 0.00 & 0.12 \\
\hline Gadoleic acid & $(\mathrm{C} 20: 1 \omega 9)$ & 0.20 & 0.20 & 0.21 \\
\hline 9-Eicosaenoic acid & $(\mathrm{C} 20: 1 \omega 7)$ & 0.11 & 0.00 & 0.12 \\
\hline Arachidonic acid & $(\mathrm{C} 20: 4 \omega 6)$ & 0.41 & 0.48 & 0.53 \\
\hline \multicolumn{2}{|c|}{ Non identified fatty acids } & 0.10 & 0.02 & 0.02 \\
\hline \multicolumn{2}{|c|}{ Total saturated fatty acids } & 41.15 & 40.15 & 40.18 \\
\hline \multicolumn{2}{|c|}{ Total unsaturated fatty acids } & 58.75 & 59.83 & 59.80 \\
\hline \multicolumn{2}{|c|}{ Total fatty acids } & 99.90 & 99.98 & 99.98 \\
\hline
\end{tabular}

Table 6. Amino acids composition of different chicken luncheon samples

\begin{tabular}{|c|c|c|c|c|}
\hline \multirow{2}{*}{$\begin{array}{l}\text { Amino acids } \\
(\%)\end{array}$} & & \multicolumn{3}{|c|}{ Treatments } \\
\hline & & $\mathbf{C L}^{\mathrm{a}}$ & $\mathbf{T 1}^{\mathrm{b}}$ & $T 2^{\mathrm{c}}$ \\
\hline Therionine & (Thr) & 2.45 & 2.43 & 2.41 \\
\hline Valine & (Val) & 3.17 & 2.92 & 2.89 \\
\hline Methionine & (Met) & 1.22 & 1.29 & 1.30 \\
\hline Isoleucine & (Ile) & 2.80 & 2.77 & 2.73 \\
\hline Leucine & (Leu) & 4.47 & 4.49 & 4.41 \\
\hline Tyrosine & (Tyr) & 1.36 & 1.22 & 0.92 \\
\hline Phenyalanine & (Phe) & 2.25 & 2.21 & 2.25 \\
\hline Lysine & (Lys) & 3.70 & 3.84 & 3.74 \\
\hline Histidine & (His) & 1.81 & 1.77 & 1.75 \\
\hline Aspartic & (Asp) & 5.05 & 4.81 & 4.65 \\
\hline Serine & (Ser) & 2.22 & 2.26 & 2.15 \\
\hline Glutamic & (Glu) & 9.75 & 9.18 & 8.97 \\
\hline Prolin & (Pro) & 2.42 & 2.09 & 2.18 \\
\hline Glycine & (Gly) & 2.79 & 2.73 & 2.52 \\
\hline Alanine & (Ala) & 3.94 & 3.94 & 3.82 \\
\hline Cystine & (Cys) & 0.74 & 0.59 & 0.72 \\
\hline Arginine & (Arg) & 3.48 & 3.29 & 3.24 \\
\hline
\end{tabular}

Microbial examination of different chicken luncheon samples during cold storage $\left(4 \pm 1^{\circ} \mathrm{C}\right)$

Results in Table (7) indicated that total bacterial count, psychrophilic bacteria, spore forming bacteria, total molds and yeasts of different chicken luncheon samples during cold storage at $4 \pm 1^{\circ} \mathrm{C}$. The best treatment to inactivation of microbial loud was $\mathrm{T} 2$ followed by $\mathrm{T} 1$ in chicken luncheon samples compared with other samples.

Table 7. Microbial examination of different chicken luncheon samples during cold storage $\left(4 \pm 1^{\circ} \mathrm{C}\right)$

\begin{tabular}{|c|c|c|c|c|c|c|}
\hline \multirow{2}{*}{$\begin{array}{l}\text { Microbiological } \\
\text { parameters }\end{array}$} & \multirow{2}{*}{$\begin{array}{c}\text { Storage } \\
\text { (months) }\end{array}$} & \multicolumn{5}{|c|}{ Treatments } \\
\hline & & $\mathrm{CL}^{\mathrm{a}}$ & $\mathbf{T 1}^{\mathrm{b}}$ & $\mathbf{T} 2^{\mathrm{c}}$ & $\mathbf{T 3}^{\mathrm{d}}$ & $\mathbf{T} 4^{f}$ \\
\hline \multirow{5}{*}{ Total bacterial count } & 1 & $3.6 \times 10^{2}$ & $3.6 \times 10^{2}$ & $3.5 \times 10^{2}$ & $3.7 \times 10^{2}$ & $4 \times 10^{2}$ \\
\hline & 2 & $5.9 \times 10^{2}$ & $5.0 \times 10^{2}$ & $4.9 \times 10^{2}$ & $5.4 \times 10^{2}$ & $5.0 \times 10^{2}$ \\
\hline & 3 & $7.5 \times 10^{2}$ & $5.5 \times 10^{2}$ & $6.0 \times 10^{2}$ & $7.3 \times 10^{2}$ & $7.0 \times 10^{2}$ \\
\hline & 4 & ß & $7.1 \times 10^{2}$ & $7.0 \times 10^{2}$ & ( & (R) \\
\hline & 5 & & ® & ( & & \\
\hline \multirow{5}{*}{ Psychrophilic bacteria } & 1 & $1.0 \times 10^{2}$ & $1.1 \times 10^{2}$ & $1.2 \times 10^{2}$ & $1.1 \times 10^{2}$ & $1.2 \times 10^{2}$ \\
\hline & 2 & $2.5 \times 10^{2}$ & $1.9 \times 10^{2}$ & $1.8 \times 10^{2}$ & $2.5 \times 10^{2}$ & $2.4 \times 10^{2}$ \\
\hline & 3 & $3.6 \times 10^{2}$ & $2.7 \times 10^{2}$ & $2.6 \times 10^{2}$ & $3.3 \times 10^{2}$ & $3.2 \times 10^{2}$ \\
\hline & 4 & (B) & $3.1 \times 10^{2}$ & $3.2 \times 10^{2}$ & (B) & (B) \\
\hline & 5 & & ® & (B) & & \\
\hline \multirow{5}{*}{ Spore-forming bacteria } & 1 & $2.4 \times 10^{2}$ & $2.0 \times 10^{2}$ & $2.0 \times 10^{2}$ & $2.2 \times 10^{2}$ & $2.1 \times 10^{2}$ \\
\hline & 2 & $3.1 \times 10^{2}$ & $2.7 \times 10^{2}$ & $2.6 \times 10^{2}$ & $2.9 \times 10^{2}$ & $2.8 \times 10^{2}$ \\
\hline & 3 & $3.5 \times 10^{2}$ & $2.9 \times 10^{2}$ & $3.0 \times 10^{2}$ & $3.2 \times 10^{2}$ & $3.1 \times 10^{2}$ \\
\hline & 4 & ® & $3.3 \times 10^{2}$ & $3.2 \times 10^{2}$ & ® & ( ) \\
\hline & 5 & & ( & ( & & \\
\hline \multirow{5}{*}{ Total molds\& yeasts } & 1 & $3.2 \times 10^{2}$ & $3.0 \times 10^{2}$ & $2.9 \times 10^{2}$ & $3.0 \times 10^{2}$ & $3.0 \times 10^{2}$ \\
\hline & 2 & $7.2 \times 10^{2}$ & $4.0 \times 10^{2}$ & $3.9 \times 10^{2}$ & $5.1 \times 10^{2}$ & $5.0 \times 10^{2}$ \\
\hline & 3 & $8.2 \times 10^{2}$ & $6.0 \times 10^{2}$ & $5.9 \times 10^{2}$ & $6.3 \times 10^{2}$ & $6.2 \times 10^{2}$ \\
\hline & 4 & (B) & $7.2 \times 10^{2}$ & $7.0 \times 10^{2}$ & ( ) & (B) \\
\hline & 5 & & ® & ® & & \\
\hline
\end{tabular}

®: At these points samples were rejected.

$\mathrm{CL}^{\mathrm{a}}$ : Basal formula without any additional ingredients (Control luncheon)

$\mathrm{T}^{\mathrm{c}}$ : Basal formula+ fresh turnip plant roots

T4 ${ }^{\mathrm{f}}$ : Basal formula + (Lentils seeds powder +

These reduction in microbial loud of $\mathrm{T} 2$ and $\mathrm{T} 1$ treatments and its effectiveness to extend shelf-life of chicken luncheon might be due to the presence of phenolic, flavonoids and carotenoids represented antioxidant, antimicrobial compounds and anticancer activity, these results are in agreement with those mentioned by Fahey et
$T^{\text {b }}$ : Basal formula + lentils seeds powder T3 $^{\text {d }}$ : Basal formula+ fresh cauliflower al., (2001); Zhang et al., (2008); Aires et al., (2009) and Thiruvengadam et al., (2016). They mentioned that turnip contain a high amount of glucosinolates especially gluconasturtiin which cause protection against pathogens, antimicrobial and anticancer activities in humans. Also Peptides of lentils seeds have antimicrobial potential agenist 
Lens culinaris and antifungal activity against Botrytis cinerea and Neurospora crassa (Shenkarev et al. 2014; Pina-Pérez and Ferrús Pérez, 2018).

\section{CONCLUSION}

This work was carried out to use lentils seeds powder, fresh turnip plant roots and fresh cauliflower in processing of chicken luncheon to improve their quality and lower cost of chicken luncheon. The results revealed that the sensory attributes (appearance, color, texture, taste and odor) of different chicken luncheon samples during cold storage at $4 \pm 1^{\circ} \mathrm{C}$ for five months. T2 treatment scoring a significant ( $\mathrm{P}>0.05)$ highly, followed by $\mathrm{T} 1$ treatment during period's storage at $4 \pm 1^{\circ} \mathrm{C}$ which rejected after four months, while control sample, T3 and T4 treatments received significantly lower score for evaluated parameters and rejected after three months. Hence, chicken luncheon samples prepared with turnip plant and lentils were scored the best treatment, compared to the other samples. The palmitic acid was the predominant saturated fatty acid, while oleic acid was the highest unsaturated fatty acids. The total unsaturated fatty acids for oils extracted from chicken luncheon samples recorded $58.75,59.83$ and $59.8 \%$, while the total saturated fatty acids amounted to $41.15,40.15$ and $40.18 \%$ for oils extracted from CL, T1 and T2 treatments respectively. Leucine is the major essential amino acid in all treatments. It reached between $4.41 \%$ (T2 sample) and $4.49 \%$ (T1 sample). Glutamic acid showed higher ratio of non-essential amino acid ranged between $8.97 \%$ (T2) and $9.75 \%$ (control sample). The results also, showed that a reduction in microbial loud (total molds and yeasts, total bacterial, psychrophilic bacteria and spore-forming bacteria) of T2 and T1 treatments and its effectiveness to extend shelf-life of chicken luncheon, this reduction might be due to the presence of bioactive compounds (flavonoids and phenolic compounds) hence improving its quality.

\section{REFERENCES}

Abdullah, B. M. (2007) Properties of five canned luncheon meat formulations as affected by quality of raw materials. International Journal of Food Science and Technology 42, 30-35.

Aires, A., V. R. Mota, M. J. Saavedra, E. A. S. Rosa and Bennett R. N. (2009) The antimicrobial effects of glucosinolates and their respective enzymatic hydrolysis products on bacteria isolated from the human intestinal tract. Journal of Applied Microbiology, 106, 2086-2095.

Al-Bachir, M. and A. Mehio (2001) Irradiated luncheon meat: microbiological, chemical and sensory characteristics during storage. Food Chemistry, 75, 169-175.

Ansorena, D. and I. Astiasarán. (2013). 10 - Enrichment of meat products with omega- 3 fatty acids by methods other than modification of animal diet. In Food Enrichment with Omega-3 Fatty Acids, eds. C. Jacobsen, N. S. Nielsen, A. F. Horn \& A.-D. M. Sørensen, 299-318. Woodhead Publishing.

AOAC (2016) Association of Official Analytical Chemist., EUA.

APHA (1992) Compendium of Methods for the Microbiological Examination of Foods"(2nd ed.), American Puplic Heath Association, Washinton DC.
Bamdad, F., A. H. Goli and M. Kadivar (2006) Preparation and characterization of proteinous film from lentil (Lens culinaris): Edible film from lentil (Lens culinaris). Food Research International, 39, 106-111.

Crandall, P. G., C. A. O'Bryan, R. Peterson, N. Dyenson and F. Yiannas (2015) A survey estimating the benefits of incorporating Listeria specific growth inhibitors in bulk luncheon meats to be sliced in retail delis. Food Control, 53, 185-188.

Egan, H. I., Kirk, R. S. and Sawyer, R. (1981 ) Person's. Chemical Analysis of Food. 8th ed., Churchill Livingstogne, Edintugh.

Fahey, J. W., A. T. Zalcmann and P. Talalay (2001) The chemical diversity and distribution of glucosinolates and isothiocyanates among plants. Phytochemistry, 56, 5-51.

FDA, F. a. D. A. (2002). Bacteriological Analytical Manual. 9th Ed.,AOAC Int., Arlington, VA,USA.

Gombas, D. E., Y. Chen, R. S. Clavero and V. N. Scott (2003) Survey of Listeria monocytogenes in Ready-to-Eat Foods. Journal of Food Protection, 66, 559-569.

Gross, J. L., T. Zelmanovitz, C. C. Moulin, V. De Mello, M. Perassolo, C. Leitão, A. Hoefel, A. Paggi and M. J. Azevedo (2002) Effect of a Chicken-Based Diet on Renal Function and Lipid Profile in Patients With Type 2 Diabetes. A randomized crossover trial, 25, 645-651.

Hayes, J. E., I. Canonico and P. Allen (2013) Effects of organic tomato pulp powder and nitrite level on the physicochemical, textural and sensory properties of pork luncheon roll. Meat Science, 95, 755-762.

Hefnawy, T. H. (2011) Effect of processing methods on nutritional composition and anti-nutritional factors in lentils (Lens culinaris). Annals of Agricultural Sciences, $56,57-61$.

Islam, M., J. Chen, D. Doyle and M. Chinnan ( 2002) Effect of Selected Generally Recognized as Safe Preservative Sprays on Growth of Listeria monocytogenes on ChickenLuncheon MeatEffect of Selected Generally Recognized as Safe Preservative Sprays on Growth of Listeria monocytogenes on Chicken Luncheon Meat. Journal of Food Protection, 65, 794-798.

Jarpa-Parra, M., F. Bamdad, Y. Wang, Z. Tian, F. Temelli, J. Han and L. Chen (2014) Optimization of lentil protein extraction and the influence of process $\mathrm{pH}$ on protein structure and functionality. LWT - Food Science and Technology, 57, 461-469.

Jelen, P., R. A. Lawrence and M. Cerrone (1982) Evaluation of Alkali Extracted Chicken Protein for Use in Luncheon Meats. Food Sci. Techllol. , 15, 289-293.

Leusink, G., H. Rempel, B. Skura, M. Berkyto, W. White, Y. Yang and M. S. Diarra (2010) Growth performance, meat quality, and gut microflora of broiler chickens fed with cranberry extract. Poultry Science, 89, 1514-1523.

López de Lacey, A. M., M. E. López-Caballero and P. Montero (2014) Agar films containing green tea extract and probiotic bacteria for extending fish shelf-life. $L W T$ Food Science and Technology, 55, 559-564.

Lunden, J. M., T. J. Autio, A. M. SjÖBerg and H. J. Korkeala (2003) Persistent and Nonpersistent Listeria monocytogenes Contamination in Meat and Poultry Processing Plants. Journal of Food Protection, 66, 2062-2069.

Medina-Jaramillo, C., O. Ochoa-Yepes, C. Bernal and L. Famá (2017) Active and smart biodegradable packaging based on starch and natural extracts. Carbohydrate Polymers, 176, 187-194. 
Mohamed, F. K., H. M. Sobhy, W. Z. Azer, M. E. E.-D. Manal, H. M. Z. Ali and S. A. El-askalany (2014) Fatty acid profile, antioxidant activity of various suggested chicken burger treatments. Annals of Agricultural Sciences, 59, 47-51.

Mohammed, H. N. (2013) Study of some chemical, physical, sensory and bacteriology characteristics of canned chicken meat imported to Sulaymaniyah markets, Iraq. International Journal of Nutrition and Metabolism, 5 128-133.

Ochoa-Yepes, O., L. Di Giogio, S. Goyanes, A. Mauri and L. Famá (2019) Influence of process (extrusion/thermocompression, casting) and lentil protein content on physicochemical properties of starch films. Carbohydrate Polymers, 208, 221-231.

Oxoid, T. o. M. (1998) (8th ed.)Oxid ltd., Wade Road, Basingstoke, Hampshire, R G24 8PW, Engand.

Pina-Pérez, M. C. and M. A. Ferrús Pérez (2018) Antimicrobial potential of legume extracts against foodborne pathogens: A review. Trends in Food Science \& Technology, 72, 114-124.

Romans, J. R., W. J. Costello, C. W. Carlson, M. L. Greaser and K. W. Jones (1994) The Meat We Eat. Interstate Publisher Inc., Danville IL.

Rozoy, É., L. Bazinet, M. Araya-Farias, A. Guernec and L. Saucier (2013) Inhibitory effectsof commercial and enriched green tea extracts on the growth of meat spoilage bacteria. Journal of Food Research, 2, 1-7.

Sams, C. E., D. R. Panthee, C. S. Charron, D. A. Kopsell and J. S. Yuan (2011) Selenium regulates gene expression for glucosinolate and carotenoid biosynthesis in Arabidopsis. . Journal of the American Society for Horticultural Science, 136, , 23-34.

Sanz-Puig, M., M. C. Pina-Pérez, D. Rodrigo and A. MartínezLópez (2015) Antimicrobial activity of cauliflower (Brassica oleracea var. Botrytis) by-product against Listeria monocytogenes. Food Control, 50, 435-440.

Saucier, L. (2016) Microbial spoilage, quality and safety within the context of meat sustainability. Meat Science, 120, 78-84.

SAS, (1998).User's Guide Statitics Version 6 Eddition. SAS Institute Inc-Cary.Nc.USA

Shenkarev, Z. O., A. K. Gizatullina, E. I. Finkina, E. A. Alekseeva, S. V. Balandin, K. S. Mineev, A. S. Arseniev and T. V. Ovchinnikova (2014) Heterologous expression and solution structure of defensin from lentil Lens culinaris. Biochemical and Biophysical Research Communications, 451, 252-257.
Stojceska, V., P. Ainsworth, A. Plunkett, E. İbanoğlu and Ş. İbanoğlu (2008) Cauliflower by-products as a new source of dietary fibre, antioxidants and proteins in cereal based ready-to-eat expanded snacks. Journal of Food Engineering, 87, 554-563.

Su, J.-F., X.-Y. Yuan, Z. Huang, X.-Y. Wang, X.-Z. Lu, L.-D. Zhang and S.-B. Wang (2012) Physicochemical properties of soy protein isolate/carboxymethyl cellulose blend films crosslinked by Maillard reactions: Color, transparency and heat-sealing ability. Materials Science and Engineering: C, 32, 40-46.

Sun, S., P. Liu, N. Ji, H. Hou and H. Dong (2018) Effects of various cross-linking agents on the physicochemical properties of starch/PHA composite films produced by extrusion blowing. Food Hydrocolloids, 77, 964-975.

Thiruvengadam, M., S.-H. Kim and I.-M. Chung (2016) Influence of amphetamine, $\gamma$-aminobutyric acid, and fosmidomycin on metabolic, transcriptional variations and determination of their biological activities in turnip (Brassica rapa ssp. rapa). South African Journal of Botany, 103, 181-192.

USDA (2009) Draft FSIS comparative risk assessment for Listeria monocytogenes in ready-to-eat meat and poultry deli meats. Available at http:// www.gpo. gov/fdsys/pkg/FR-2009-04-09/pdf/E9-8056.pdf Accessed 01.08.14.

Volden, J., G. B. Bengtsson and T. Wicklund (2009) Glucosinolates, l-ascorbic acid, total phenols, anthocyanins, antioxidant capacities and colour in cauliflower (Brassica oleracea L. ssp. botrytis); effects of long-term freezer storage. Food Chemistry, 112, 967976.

Weatherill, S. (2009) Report of the independent investigator into the 2008 listeriosis outbreak. Government of Canada. ListeriaIndependentInvestigatorReport_July212009.

Zhang, B., Z. Deng, Y. Tang, P. Chen, R. Liu, D. D. Ramdath, Q. Liu, M. Hernandez and R. Tsao (2014) Fatty acid, carotenoid and tocopherol compositions of 20 Canadian lentil cultivars and synergistic contribution to antioxidant activities. Food Chemistry, 161, 296-304.

Zhang, H., I. Schonhof, A. Krumbein, B. Gutezeit, L. Li, H. Stützel, M. Schreiner and (2008) Water supply and growing season influence glucosinolate concentration and composition in turnip root (Brassica rapa ssp. rapifera L.). Journal of Plant Nutrition and Soil Science $171255-265$.

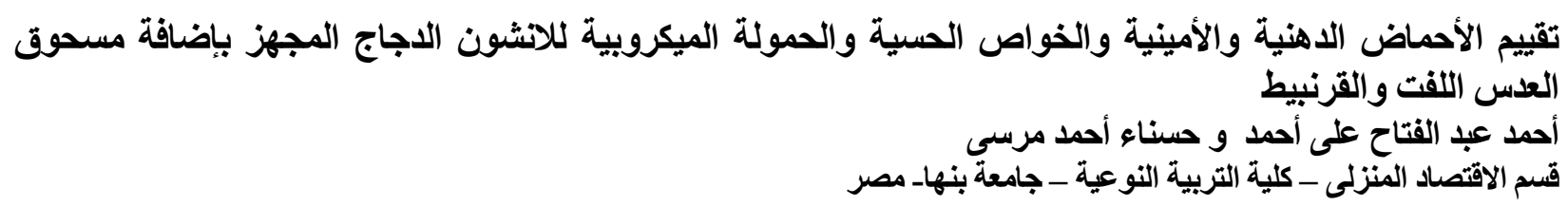

الهذف من هذه الدر اسة هو استخدام بعض النباتات مثل العدس ونبات اللفت والقات القرنبيط في تصنيع لانشون الفر اخ لخفض تكلفة الإنتاج وتعزيز القيمة الغذائية له. شملت

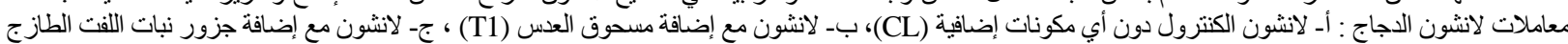

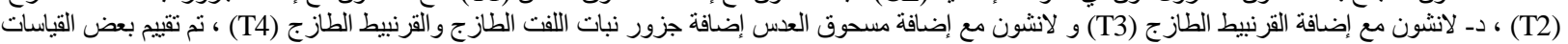

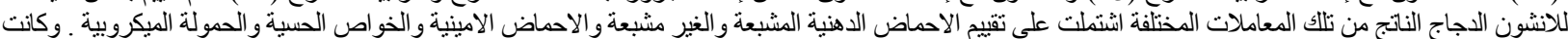

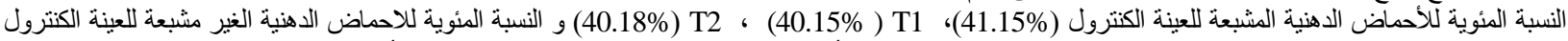

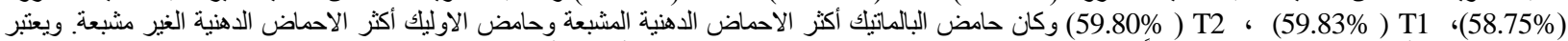

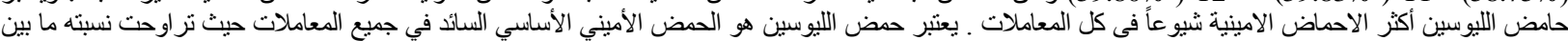

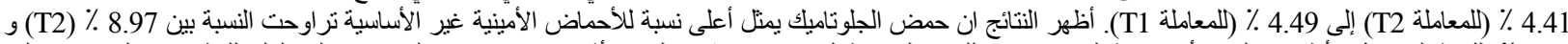

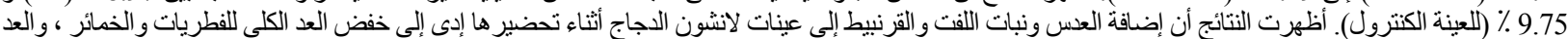

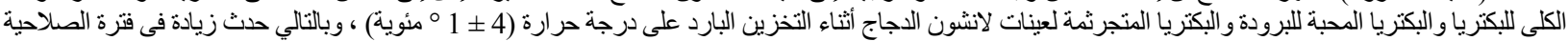

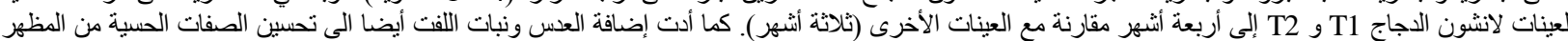

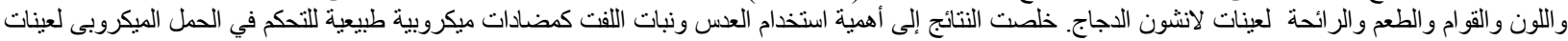

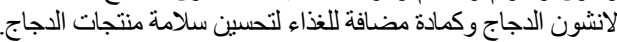

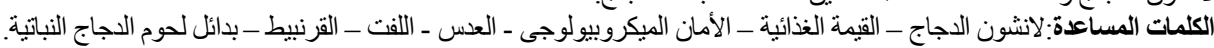

